COBISS: 1.08

\title{
UNDERGROUND TIMAVO RIVER MONITORING (CLASSICAL KARST)
}

MONITORING PODZEMELJSKE REKE TIMAVE (KRAS)

FRANCO CUCCHI ${ }^{1} \&$ LUCA ZINI $^{1}$

${ }^{1}$ Dipartimento di Scienze Geologiche, Ambientali e Marine - Università di Trieste, Via E. Weiss, 2, I-34127 TRIESTE, ITALY

Prejeto / received: 20. 3. 2002 


\section{Franco Cucchi \& Luca Zini: Monitoring podzemeljske reke Timave (Kras)}

Instrumenti, ki zvezno merijo nivo, temperaturo in prevodnost vode so bili postavljeni na 10 točkah. Opazovalna mesta so postavljena na dnu, kjer jama doseže vode Reke (Timave), ki zbira podzemne vode klasičnega Krasa. Predhodne analize velikega števila podatkov, ki smo jih zbrali do sedaj, pomagajo bolje določiti način pretakanja vode $\mathrm{v}$ globinah. Ugotovili smo tri različne vodne valove, vpliv črpanja na nekaterih delih in mešanje različnih voda na drugih.

Ključne besede: zvezno opazovanje vode, senzorji za temperaturo, prevodnost in nivo, klasični Kras, Italija, Slovenija.

\section{Abstract \\ Franco Cucchi \& Luca Zini: Underground Timavo river monitoring (Classical Karst)}

UDC: $556.3(450)$

Some instruments that continuously measure height, temperature and conductivity of waters have been placed in 10 stations. The stations are located on the bottom of the cavities that reach the waters of the Timavo, the underground river that collects the hypogean waters of the Classical Karst. The preliminary analysis of the remarkable amount of data that has been collected up to now helps define the modalities of water circulation in depth better. There are three different types of flood wave, pumping effects in some tracts and mixing of different waters in other tracts.

Key words: water monitoring, temperature sensor, conductivity sensors, level sensor, Classical Karst, Italy, Slovenia. 


\section{INTRODUCTION}

In order to improve the data on the underground aquifer of the Classical Karst the Department of Geological, Environmental and Marine Sciences of Trieste University (DiSGAM) has started a research upon the physical-chemical characteristics of the groundwaters in the cavities reached by them ${ }^{1}$. Since April 1994 up to now some stations measuring in continuum the conductivity, the temperature and the height of the waters of the underground Timavo river have been activated ${ }^{2}$.

The instruments placed consist of a mix of particularly suitable serial instruments, a serial equipment fitted for specific needs and assembled in the laboratories of DiSGAM, equipment thought of , built and constantly up-dated directly in the laboratories of DiSGAM.

\section{SENSORS}

The depth sensors are realised by DiSGAM using advanced low consumption electronics; they are placed in suitable metallic containers extremely tough that are plunged into water. They measure the water level by recording the weight of the overhanging water column and they read centimetre variations. The container is a stainless steel cylinder that has a diameter of $41 \mathrm{~mm}$, that is $155 \mathrm{~mm}$ long and that weights about $525 \mathrm{~g}$. The datalogger inside it can memorise up to 16,000 data and the sensor may be fitted for reading different water fluctuations of 1, 2, 10, 20, 30, 80 metres high. The resolution is of $0.4 \%$. The feeding is autonomous with litium and/or alkaline long term batteries. The working autonomy is of at least one year, the data are recorded and transferred by computer using our own programme. The data, then, may be directly processed using any electronic sheet.

An external level meter has been programmed in order to record the height of free flowing waters having a fluctuation range of $550 \mathrm{~mm}$. The height of the waters is recorded by a floating bag connected to a mobile arm that measures variations with the resolution of $1 \mathrm{~mm}$. The system consists in the conversion of the angular variation of the arm in a measure of linearised level (Crevatin et al., 1999).

Conductivity and temperature sensors have been mounted at DiSGAM laboratory; they are quality instruments (HANNA Instruments) adapted and connected to special micro-electrical sheets, in order to make them work autonomously and to be able to programme them for in continuum measurements.

The cylindrical container, which is plunged into the water and fixed to the rock, is made up of anodised anticorodal. It contains the instrument, feeding and sensors and it is supplied with a pressurisation system up to $10 \mathrm{~kg} / \mathrm{cm}^{2}$ that enables a theoretical plunge of 100 metres. Its length is of $58 \mathrm{~cm}$, its diameter of $10 \mathrm{~cm}$ and its weight of $4.55 \mathrm{~kg}$.

\footnotetext{
${ }^{1}$ The campaign is partly supported by Ministry for Education, University and Research (MIUR)" with 60\% funds and mostly by National Group for Prevention of Hydrogeological Disasters (G.N.D.C.I.) of National Research Council of Italy (C.N.R.). - Research Line n. 4: "Evaluation of the Vulnerability of Aquifers" (prof. M. Civita coordinator).

${ }^{2}$ It is a complex, long often hard operation: Giacomo Casagrande, Marco Comar, Gabriele Crevatin, Paolo Manca, Enrico Marinetti have contributed to it.
} 
A level, temperature and conductivity datalogger, the CTD-Diver built by Eijkelkamp (The Netherlands) has been recently started. If it proves to be suitable for operating in cavity and sometimes under difficult conditions, it will gradually replace the prototypes built at DiSGAM. The absolute water-tightness, minimum weight $(300 \mathrm{~g})$, reduced size (diameter equal to $22 \mathrm{~mm}$ and length equal to $260 \mathrm{~mm})$, high memory capacity $(3 \times 16,000$ measurements), data processing and transfer via optical cable to any personal computer remarkably favour this instrument.

\section{MEASUREMENT STATIONS}

In November 2001 instruments were located in 10 stations placed (figure 1):

1 - at 320 a.s.l. in the Skocjanske Jame $(\mathrm{SI})^{3}$, at three hundred metres from the entrance and in correspondence of "Ranke bridge": a depth sensor (0-100 m), a conductivity and temperature sensor;

2 - at $56 \mathrm{~m}$ a.s.l. in the "Antro delle Sorgenti di Bagnoli" (Bagnoli springs): a depth sensor (0-5 m);

3 - at $11.7 \mathrm{~m}$ a.s.l. in the Lindner Hall of Trebiciano cave: 2 depth sensors (0-10 $\mathrm{m}$ and 0-30 m), 2 conductivity and temperature sensors;

4 - at $3.5 \mathrm{~m}$ a.s.l. in the Medeot Hall of Lazzaro Jerko cave: 2 depth sensors (0-10 $\mathrm{m}$ and 0-30 $\mathrm{m})$, a conductivity and temperature sensor;

5 - at $2.5 \mathrm{~m}$ a.s.l. at the bottom of Lindner cave: a depth sensor $(0-30 \mathrm{~m})$;

6 - at $0.5 \mathrm{~m}$ a.s.1. at Aurisina Springs: a depth sensor (0-2 m);

7 - at $1 \mathrm{~m}$ a.s.l. in the Colombi cave: a depth sensor (0-10 m);

8 - at $1 \mathrm{~m}$ a.s.l. near the "San Giovanni di Duino" springs: a depth sensor (0-1 m) balanced by atmospheric pressure, a conductivity and temperature sensor;

9 - at $2.2 \mathrm{~m}$ a.s.l. in the inflowing channel of the Pietrarossa lake a depth sensor $(0-1 \mathrm{~m})$ balanced by atmospheric pressure;

10 - at $3.6 \mathrm{~m}$ a.s.1. near the inversac of the Doberdò lake: a depth sensor $(0-1 \mathrm{~m})$ balanced by the atmospheric pressure.

\section{SOME RESULTS}

The analysis of the data collected up to now has just started. However, some particular events have been analysed in order to programme the studies and future comparisons better and better.

For example, it has been proven (Cucchi et al., 1997) that the annual fluctuation of water temperature of the underground Timavo is of $23^{\circ} \mathrm{C}$ (from $0^{\circ}$ to $23.0^{\circ}$ ) at the entrance of Škocjan cave, of $7.6^{\circ}$ (from $6.4^{\circ}$ to $14.0^{\circ}$ ) Trebiciano cave, and of $8^{\circ}$ (from $7.8^{\circ}$ to $15.8^{\circ}$ ) at the resurgences.

\footnotetext{
${ }^{3}$ We would like to thanks the colleagues of the "Inštitut za raziskovanje krasa" of Postojna, who have collaborated with us in these researches for a long time and the Direction of the Park "Škocjanske jame" that allows us to work inside the famous tourist cave.
} 


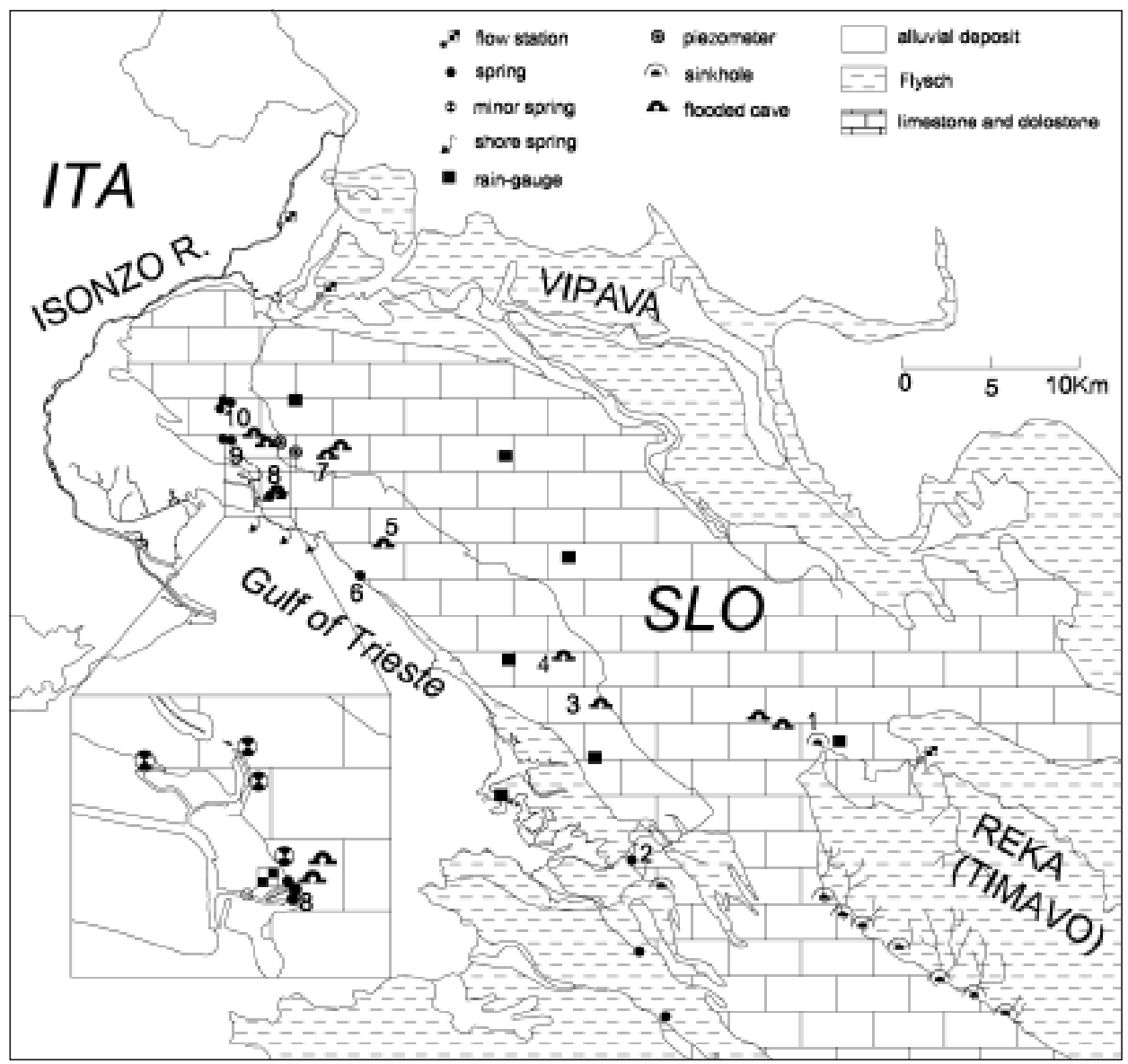

Fig. 1: Location of monitoring stations: 1) Škocjan cave (Reka - Upper Timavo stream sink), 2) “Antro di Bagnoli" spring, 3) Trebiciano Abyss, 4) Lazzaro Jerko cave, 5) Lindner cave, 6) Aurisina springs, 7) Colombi cave, 8) "San Giovanni di Duino" springs (Timavo resurgences), 9) Pietrarossa lake, 10) Doberdò lake.

The conductivity decreases during floods, however the quantity of variations and their regime depend upon the ratios between percolating waters, rich in solute, and fluvial waters swallowed up in Škocjan cave, which have low solute values but abundant suspended material.

The speed of the impulse of the flood wave during the biggest episodes, those with flows at the resurgences higher than $90 \mathrm{~m}^{3} / \mathrm{sec}$, is variable and does not always depend upon the quantity of rainfalls: the tract between the swallow-hole and the Abyss of Trebiciano (less than $20 \mathrm{~km}$ ) activate within times that range from 10-12 hours to 24-30 hours, the tract between Trebiciano cave and the resurgences (again a little less than $20 \mathrm{~km}$ ) in variable times between $4-5$ hours and 20-24 hours. 
Results of the survey in the lake of Doberdò confirmed that the characteristics and modalities of filling and emptying of the lake are linked to rainfalls and to the regime of the groundwaters flowing from hypogean galleries in pressure that are fed by the near hydrogeological system of the Timavo and, especially during low waters, by that of the Isonzo (Soča) and Vipava rivers (Cucchi et al., 2000). The fluctuations of the level of the lake are not conditioned by the sea regime and are higher than $6 \mathrm{~m}$.

Almost one hundred of flood events have been analysed first. For each flood and each site monitored the beginning - climax - end of the flood, as well as the height reached by waters and the increasing and decreasing speed of the flood have been recorded. This first analysis allowed at least three typologies of flood at the resurgences to be identified. They are linked each time to the presence or not of the contribution of the different drainages that feed the spring system of the Timavo river. The resurgences are connected to the waters flowing from south-west of the upper Timavo (Reka river) and of Trebiciano cave, to those flowing from north-east that is from the basin of Brestovica, to those flowing from the north and from north-west that is the waters of the Isonzo (Soča) - Vipava basin. At the "San Giovanni di Duino" springs the conductivity during floods has shown the outflowing of reservoir waters from the aquifer, often underlining the existence of different arrivals of waters during only one flood phase (figure 2 and 3 ).

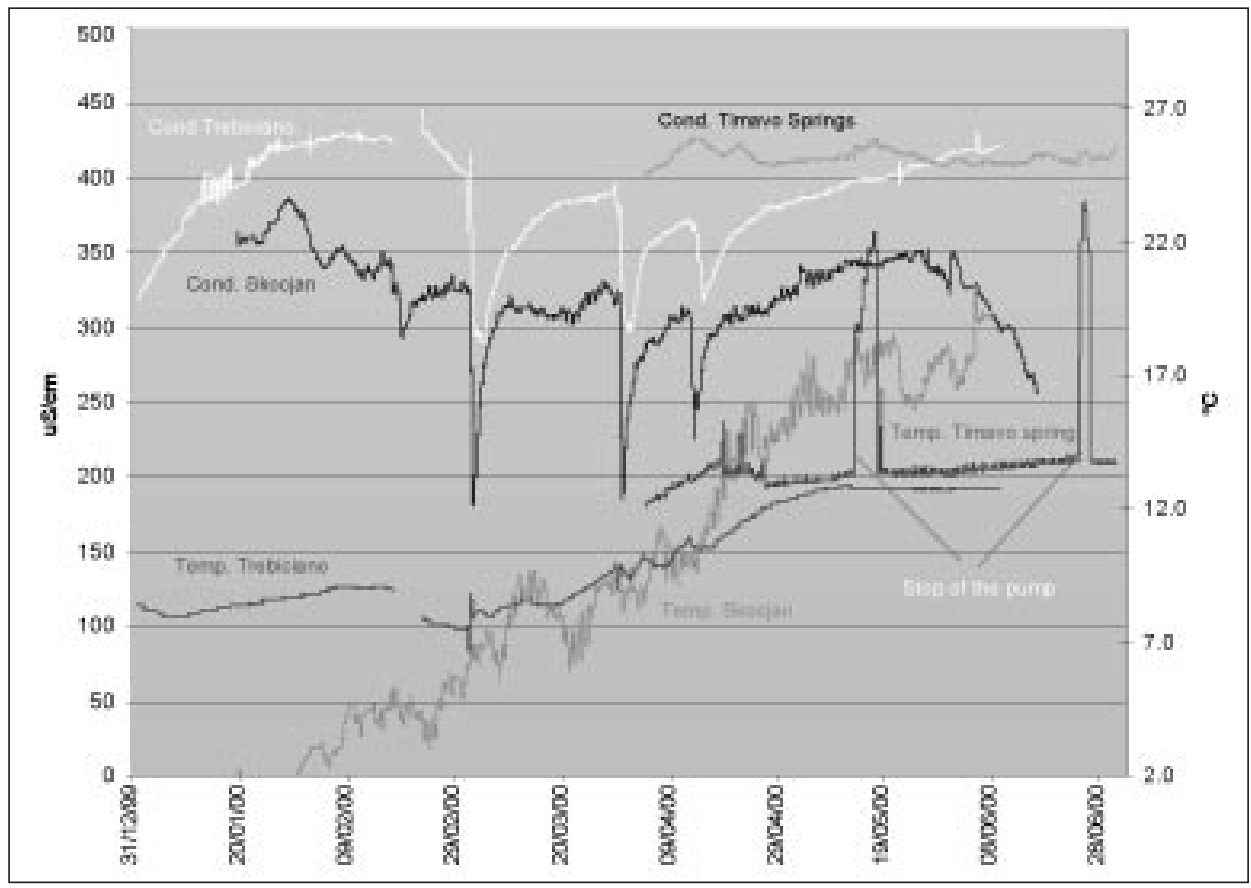

Fig. 2: Trend of the temperature and conductivity values of the waters during the period from the $1^{\text {st }}$ of January 1999 to the $30^{\text {th }}$ of June 1999 in the caves of Škocjan and Trebiciano and at Timavo resurgences. 


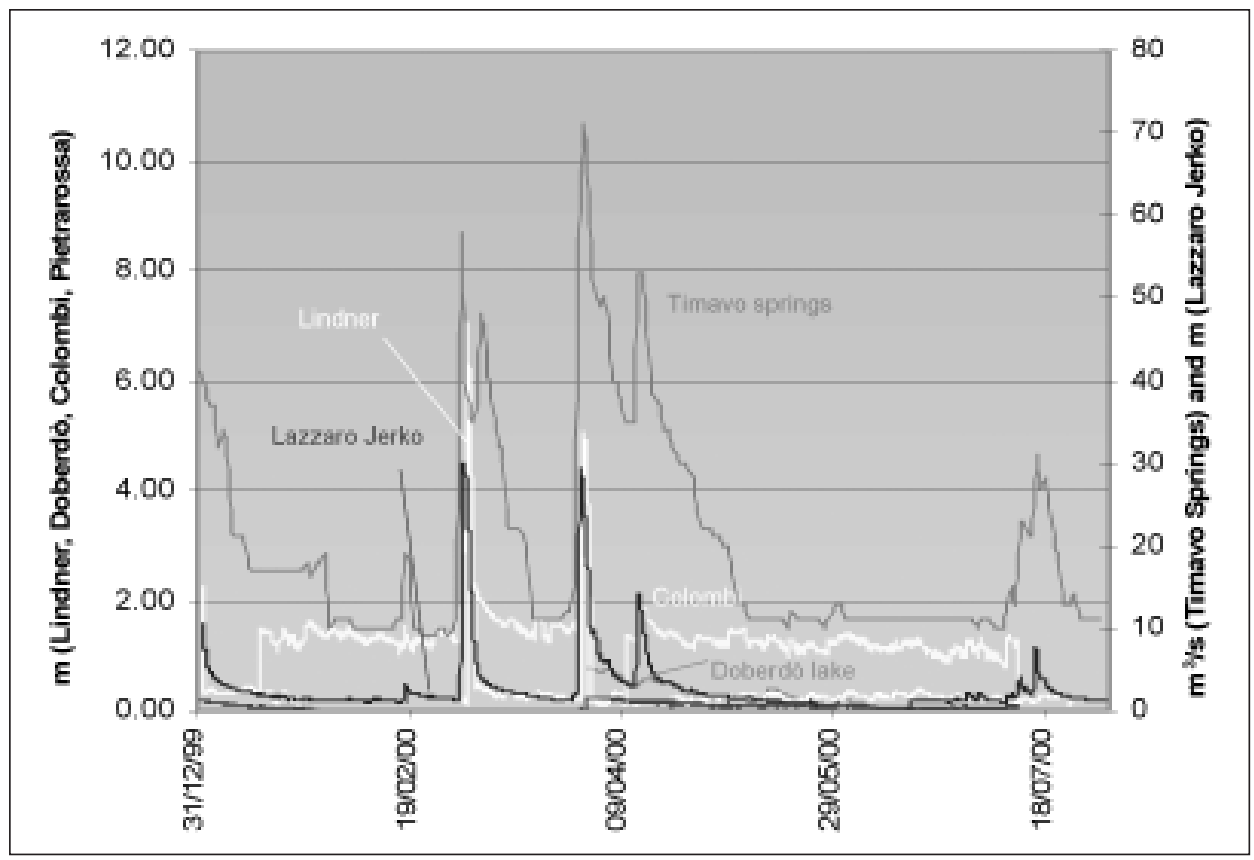

Fig. 3: Trend of the flow and height values of the waters during the period from the $1^{\text {st }}$ of January 2000 to the $30^{\text {th }}$ of July 2000 in the caves of Lazzaro Jerko, Lindner, Colombi and at Doberdò lake and Timavo resurgences

The analysis of the trend of the temperature and conductivity during floods was particularly significant for the tract Škocjan - Trebiciano - Lazzaro Jerko, and has pointed out the existence of a direct drainage among these cavities.

In Trebiciano cave and Lazzaro Jerko cave (cavities far one from the other $3.5 \mathrm{~km}$ ), floods start at the same time, temperature and conductivity fluctuations are practically contemporaneous and have a similar trend (Cucchi et al., 2001). The hydraulic system is immediately fed by rainfalls, the underground flow is rapid (between the caves water speed is over $800 \mathrm{~m} / \mathrm{h}$ ), the renewal is remarkable (figure 4).

Stronger flow mobilise deep waters because of hydraulic pressure, so the water level changes in a very short time. All that shows that caves are connected to the same hydraulic circuit, like two piezometric towers along the under pressure deep water conduits.

The hydrological data now emerging lead us to reconsider some "certainties": lithology is an important conditioning element on the surface, surely more important than the structural one, while in the underground it is almost only the system of discontinuity, with its families of planes of different hydroconductivity, which influences the structure of the drainage net (Cucchi, Forti et al., 2000). The "Four-state Model" by Ford \& Williams - who speak of "by chance events" in the proto evolution of deep karstification "guided" by structural and lithological features and of a 


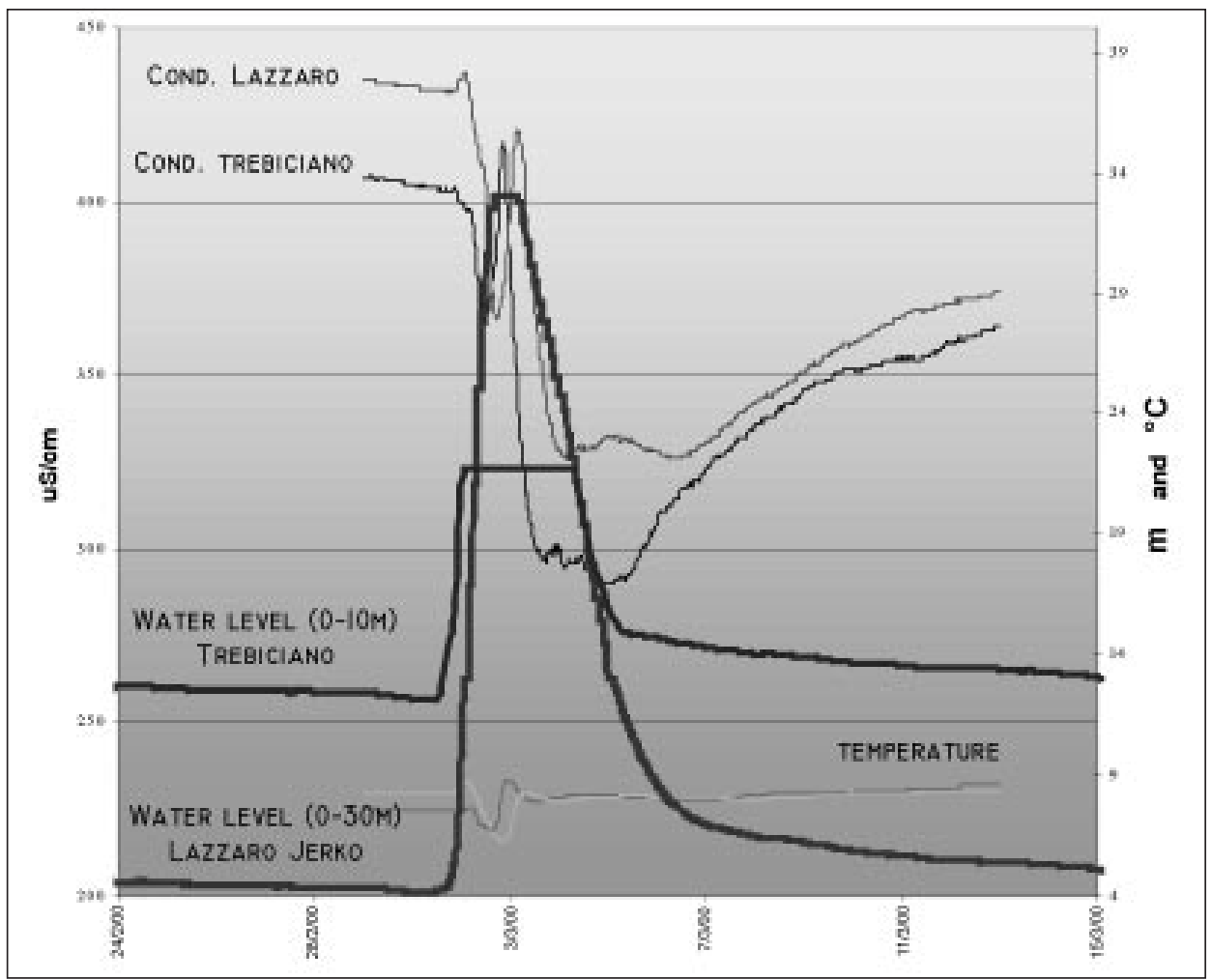

Fig. 4: Trend of the temperature, conductivity and height values of the waters during the period from the 24t of February 2000 to the $15^{\text {th }}$ of March 2000 in the caves of Trebiciano and Lazzaro Jerko.

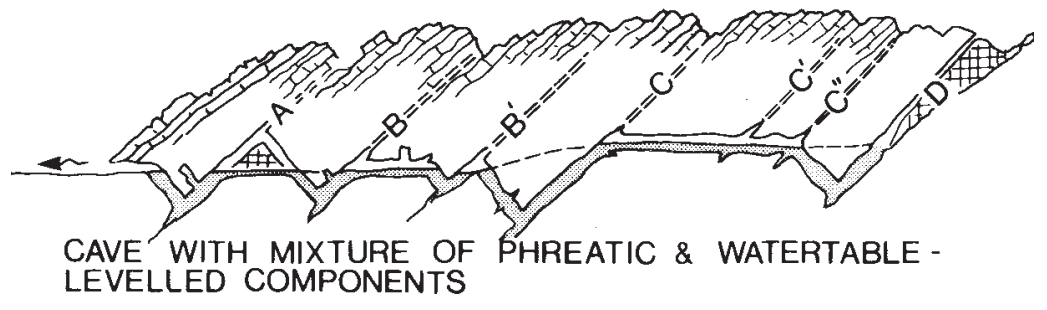

Fig. 5: The Classical Karst results to be at the $3^{\text {rd }}$ state of the "Four-state Model" proposed by Ford \& Williams for the development of common cave system in depth. (Modified from FORD D. \& WILLIAMS P. (1989): "Karst Geomorphology and Hydrology", p. 262). 
competitive development of proto-cave systems- would consequently be applicable also to the Classical Karst.

If we base ourselves upon the first results of the studies, we can undoubtedly suppose that the development of the underground aquifer of the Classical Karst results to be at the so-called $3^{\text {rd }}$ state of the evolutionary model of the underground karst proposed by Ford \& Williams (figure 5).

Paper n. 2503 of National Group for Prevention of Hydrogeological Disasters (G.N.D.C.I.) of National Research Council of Italy (C.N.R.). - Research Line n. 4: Evaluation of the Vulnerability of Aquifers" (prof. M. Civita coordinator).

\section{REFERENCES}

CUCCHI, F., GIORGETTI, F., MARINETTI, E. \& KRANJC, A., 1997: Experiences in monitoring Timavo river (Classical Karst). Tracer Hydrology 97, Kranjc (ed.): 213-218, 1997 Balkema-Rotterdam,.

CREVATIN, G., CUCCHI, F., MARINETTI, E. \& ZUPPIN, C., 1999: Strumentazione per il monitoraggio in continuo di acque carsiche; Mondo Sotterraneo, n.s., anno XXI, $n^{\circ} 1-2$ aprile-ottobre 1997: 13-24, Udine. Pubbl. n¹878 del GNDCI, LR4.

CUCCHI, F., FURLANI, S. \& MARINETTI, E., 2000: Monitoraggio in continuo del livello del lago di Doberdò. Atti e Memorie Comm. Grotte "E. Boegan”, Vol. XXXVII (1999): 143153, Trieste.

CUCCHI, F., FORTI, P., MARINETTI, E. \& ZINI, L., 2000: Recent developments in knowledge of the hydrogeology of the "Classical Karst". Acta Carsologica, Vol. 29, No. 1-4: 55-78, Ljubljana 2000,

CUCCHI, F., CASAGRANDE, G., MANCA, P. \& ZINI, L., 2001: Il Timavo ipogeo tra l'Abisso di Trebiciano e la Grotta Meravigliosa di Lazzaro Yerko (Carso Classico triestino, Italia). Le Grotte d'Italia, s. V, 2 (2001): 39-48, Iesi.

FORD, D. \& WILLIAMS, P., 1989: Karst geomorphology and hydrology. Unwin Hyman Ltd Ed.: 601 pp., Cambridge.

\section{MONITORING PODZEMELJSKE REKE TIMAVE (KRAS)}

\section{Povzetek}

$\mathrm{Z}$ analizo do sedaj zbranih podatkov smo šele pričeli. Nekaj posebnih dogodkov pa smo vseeno že analizirali, da bi bilo mogoče bolje načrtovati bodoče preučevanje in primerjanje.

Tako je bilo npr. potrjeno (Cucchi et al., 1997), da je letna amplituda temperature vode podzemeljske Timave pri vstopu v Škocjanske jame $23{ }^{\circ} \mathrm{C}$ ( od $0{ }^{\circ}$ do $23{ }^{\circ}$ ), $7,6^{\circ} \mathrm{C}$ v Labodnici (Trebiciano) $\left(\operatorname{med} 6,4^{\circ}\right.$ in $\left.14,0^{\circ}\right)$ in $8^{\circ}\left(\operatorname{med} 7,8^{\circ}\right.$ in $\left.15,8^{\circ}\right) \mathrm{v}$ izvirih.

Med poplavo prevodnost pada, seveda pa je razpon sprememb in njihova razporeditev odvisna od razmerja med prenikajočo vodo, bogato z raztopino, in rečno vodo, ki ponika v Škocjanske jame in ima majhno količino raztopine, pač pa veliko gradiva v suspenziji. 
Hitrost poplavnega vala tekom največjih dogodkov, to je takrat, ko je pretok izvirov večji od $90 \mathrm{~m}^{3} / \mathrm{s}$, se spreminja in ni vedno odvisna od količine padavin: za odsek med ponorom in Labodnico (Trebiciano) potrebuje voda med 10-12 in 24-30 ur, za odsek med Labodnico in izviri (tudi nekaj manj od $20 \mathrm{~km}$ ) pa različen čas med 4-5 in 20-24 ur.

Izsledki preučevanja Doberdobskega jezera potrjujejo, da so značilnosti in način polnjenja in praznjenja jezera vezane na padavine in na podzemeljsko vodo, ki priteka po podzemeljskih kanalih pod pritiskom, ki jih napaja bližnji hidrogeološki sistem Timave in, posebno ob nizkih vodah, tudi reki Soča in Vipava (Cucchi et al., 2000). Nihanje gladine jezera ni v odvisnosti gibanja morske gladine in presega $6 \mathrm{~m}$.

Najprej je bilo obdelanih skoraj 100 poplavnih dogodkov. Za vsak poplavni val so bili zabeleženi začetek - višek - konec poplave, višina, ki jo je dosegla vodna gladina in naraščanje ter upadanje hitrosti vode. Prve analize nakazujejo na izvirih najmanj tri tipe poplavnega vala. Vezani so na prisotnost oziroma odsotnost pritoka iz različnih prevodnikov, ki napajajo sistem reke Timave. Izviri so v zvezi z vodami, ki pritekajo z jugovzhoda iz Reke (Zgornje Timave) in iz Labodnice, s tistimi, ki pritekajo s severovzhoda iz brestoviškega bazena in s tistimi, ki pritekajo s severa in severozahoda, to je z vodami iz soško-vipavskega porečja. Prevodnost poplavne vode v izvirih pri Štivanu (San Giovanni di Duino) dokazuje, da pritekajo na dan vode, ki so bile akumulirane v vodonosniku, obenem pa nakazuje iztekanje različne vode $\mathrm{v}$ času ene same poplavne faze (Sl. 2 in 3).

Rezultati analize usmerjenosti sprememb temperature in prevodnosti poplavnega vala so posebej pomembni za odsek Škocjan - Labodnica - Lazzaro Jerko, saj kažejo, da gre za sklenjeni podzemeljski tok med temi jamami.

V Labodnici (Trebiciano) in v jami Lazzaro Jerko (med seboj oddaljeni $3.5 \mathrm{~km}$ ), se poplavni val pojavi v istem času, spremembe temperature in prevodnosti so takorekoč sočasne in imajo podobno usmerjenost (Cucchi et al., 2001). Vodni sistem neposredno napajajo padavine, podzemeljski tok je hiter (med tema jamama je hitrost toka preko $800 \mathrm{~m} / \mathrm{h}$ ) in obnavljanje vode je zelo hitro (Sl. 4).

Zaradi hidravličnega pritiska močnejši tokovi vzpodbudijo vodo $\mathrm{v}$ globinah, tako da vodna gladina niha v zelo kratkem času. Vse to dokazuje, da so jame v zvezi z istim vodnim krogotokom, podobno kot dva piezometrična stolpa vzdolž vodnih prevodnikov pod pritiskom v globinah.

Podatki, do katerih zdaj prihajamo, narekujejo, da ponovno preučimo nekaj "trdnih dejstev": litologija je gotovo zelo pomemben dejavnik na površju, gotovo pomembnejši od strukture, medtem ko je v globinah le sistem diskontinuitet, s svojimi nivoji različnih prepustnosti za vodo, tisti, ki vpliva na sestavo odtočne mreže (Cucchi, Forti et al., 2000). Ford - Williamsov model "štirih stopenj", ki govori o "slučajnostnih dogodkih" v protoevoluciji globokega zakrasevanja, ki jo vodijo strukturne in litološke oblike, in o medsebojnem tekmovanju v razvoju protokavernoznih sistemov, bi bilo torej mogoče uporabiti tudi v primeru (klasičnega) Krasa.

Če se opiramo na prve izsledke teh preučevanj, lahko nedvoumno domnevamo, da je kraški vodonosnik Krasa v tako imenovani 3. stopnji razvojnega modela kraškega podzemlja, kot ga predlagata Ford \& Williams (Sl. 5). 